Agro-Science Journal of Tropical Agriculture, Food, Environment and Extension Volume 16 Number 2 (May 2017) pp. 46 - 51

ISSN 1119-7455

\title{
THE EFFECT OF REPLACING MAIZE WITH PROCESSED CASSAVA (GARRI) ON THE PERFORMANCE, CARCASS CHARACTERISTICS AND BLOOD INDICES OF BROILER FINISHER BIRDS
}

\author{
Esiegwu, A.C. \\ Department of Animal Science and Fisheries, Imo State University, PMB 2000 Owerri, Nigeria. \\ email: arthuresiegwu@yahoo.com
}

\begin{abstract}
An experiment was carried out to determine the replacement value of maize with garri on the performance, carcass characteristics and blood indices of broiler finisher birds. Twenty-four hour fermented cassava (Garri) was used to formulate four broiler finisher diets at 0, 10, 20, and 30\% inclusion levels. Sixty, five weeks old broiler chicks were randomly assigned to four treatment diets of fifteen birds per treatment in a completely randomized design and each treatment was further replicated three times of five birds per replicate. The birds were fed for 28 days. Results show that average daily feed intake, feed conversion ratio and feed cost per $\mathrm{kg}$ weight gain of broilers did not differ significantly $(P>0.05)$ among the treatment diets. The average daily weight gain of birds was significantly decreased $(P<0.05)$ at $30 \%$ dietary level. The internal organ weights (heart, liver, and gizzard) and the dressed weights of thigh, breast muscle, wings, back muscle and neck (did not show any significant differences $(P>0.05)$. The haemoglobin $(\mathrm{Hb})$ and packed cell volume was significantly decreased at $30 \%$ dietary levels, while the white blood cell (WBC) was significantly decreased $(P<0.05)$ at $20 \%$ and $30 \%$ dietary levels. The neutrophils, basophils, eosinophils, monocytes and lymphocytes did not show any treatment effect $(P>0.05)$. Serum glutamate oxaloacetate transaminase (SGOT) and Serum glutamate pyruvate transferase (SGPT) was significantly decreased $(P<0.05)$ at $30 \%$ dietary level compared to the control. Urea and creatinine were decreased $(P<0.05)$ at 10 and $30 \%$ dietary treatment levels. No significant $(P>0.05)$ differences however existed in total proteins, albumins, globulin and cholesterol levels. It was therefore concluded that 24-hour processed cassava (garri) have potential to replace maize at $10 \%$ inclusion levels without any adverse effect on growth performance of broiler finishers.
\end{abstract}

Key words: Garri, performance, carcass, blood indices, broiler finisher.

\section{INTRODUCTION}

In Nigeria, the poultry industry has been challenged greatly by the use of maize as the main source of energy feed for the animals. Maize is also widely consumed by man in differently processed ways. Udedibie (2007) reported that, because it is a major human food and also used as raw material for various industries, its demand outstrips its supply, leading to more than $2000 \%$ increase in its price within the last 20 years. This high value placed on maize has mounted so much pressure on its demand that too many people are chasing the few tons available in the market leading to increase in price. Essentially, the high rate of inflation in Nigeria, coupled with the sudden outburst of stem borer attack on maize production since 2016 in Nigeria, that devastated hectares of maize plot, aggravated the scarcity of maize grains (Esiegwu,
2017). It is therefore necessary to research into possible alternative feed energy sources that can support maize in sustaining the poultry and livestock industry. In Nigeria, cassava and its byproducts have great potential as an important energy feed resource in diet formulations for livestock and poultry. Tsegai et al. (2002) reported that cassava is an excellent source of energy. IITA (2002) identified and highlighted the characteristics of the common forms of cassava products available in Nigeria. These include garri, fufu, cassava chips, cassava flour, starch, farina, tapioca, macaroni, cassava bread and pudding. Garri is a gritty, starch staple with high energy content which is derived from cassava (Manihot esculenta Crantz) (Ernesto et al., 2000). It is processed from fermented, gelatinized fresh cassava tubers. Cassava is high in cyanogenic glucosides, linamarin and lotaustralin which on hydrolysis yield hydrogen cyanide $(\mathrm{HCN})$ which is highly toxic (Udedibie et al., 2004; 
Effect of Replacing Maize With Processed Cassava (Garri) on the Performance of Broiler Finisher Birds

Chauynarong et al., 2009). Ojo and Akande (2013) reported the proximate composition of garri to be $1.27 \%$ crude protein, $11.74 \%$ moisture, $0.12 \%$ ash, $1.24 \%$ fibre, $1.08 \%$ fat and $84.55 \%$ carbohydrate. These nutrient values show that garri has a high energy level that could be of importance to livestock and poultry. Enidiok et al. (2008) reported the moisture, total cyanide and fiber content of garri to vary from $26.2-40.02 \%, 1.51-$ $2.81 \mathrm{mg} \mathrm{HCN} / 100 \mathrm{~g}$ and $1.80-2.40 \%$, respectively. The largest reduction in cyanide according to him took place on the third and fourth day of fermentation. Despite this anti-nutrient limitation, garri is available, cheap and has high energy component which could downplay the threat of maize scarcity and its increasing cost. This research therefore, was aimed at evaluating the feed value of garri on the performance, carcass characteristics and blood indices of broiler finishers.

\section{MATERIALS AND METHODS}

\section{Experimental site}

This experiment was carried out at the poultry unit of the teaching and research farm, Imo State University, Owerri. It is located within the SouthEastern agro-ecological zone of Nigeria. Owerri lies between latitude $5^{0} 29^{\prime}$ North and longitude $7^{0} 20^{\prime}$ East. It is about $91 \mathrm{~m}$ above sea level with annual rainfall, temperature and humidity ranging from $1,500 \mathrm{~mm}$ to $2,200 \mathrm{~mm}, 20.0-27.5^{\circ} \mathrm{C}$ and $75-$ $90 \%$, respectively (Accuweather, 2015).

\section{Source and processing of garri meal}

The fresh cassava tubers used for the experiment were bought from Umuokanne in Ohaji Egbema Local Government Area of Imo State. The cassava tubers were peeled, washed, ground into a meal with garry grating machine and put into raffia bags. Graded pressure was applied on the bags to facilitate the dewatering from the pulverized cassava. Thereafter, it was allowed to stay for 24 hours under the sun for fermentation to take place. The half-dried cassava meal was then sieved to remove the fibre. Subsequently, it was toasted for about 30 minutes at varying temperature ranges of between $80-100^{\circ} \mathrm{C}$ in an open metal pan. Samples of the garri meal were subjected to proximate and phytochemical analysis according to AOAC (2010).

\section{Experimental diets}

Four finisher broiler diets were compounded, incorporating garri meal at $0 \%, 10 \%, 20 \%$ and $30 \%$ inclusion levels respectively, partly replacing maize in the control diet. The diets were thus designated as $\mathrm{T}_{0}, \mathrm{~T}_{10}, \mathrm{~T}_{20}$ and $\mathrm{T}_{30}$ respectively. The ingredients and calculated nutrient composition of the diets are shown in Table 1.

TM/Vit.premix means Trace mineral vitamin premix

\section{Experimental birds and design}

One hundred and twenty (120) four-weeks old Agrited broiler birds bought from a reputable dealer in Owerri were used for the trial. The birds were randomly divided into four groups of 30 broilers, and each group was randomly assigned to one of the four treatment diets in a completely randomized design (CRD). Each group was replicated thrice with 10 birds per replicate, housed in a deep litter pen measuring $1 \mathrm{~m} \times 1.5 \mathrm{~m}$. Feed and water were provided ad libitum. The trial lasted for 28 days.

\section{Data collection}

The birds were weighed at the beginning of the experiment to obtain their initial body weights and thereafter on weekly basis. Daily feed intake was determined by subtracting the weight of leftover feed from the weight of the feed given the previous day. Data were collected on feed intake, body weight changes. Feed conversion ratio was calculated by dividing the average daily feed intake by average daily weight gain.

\section{Haematology and blood biochemistry}

At the end of the 28 day feeding trial, blood samples were collected from 3 birds per treatment. $2 \mathrm{mls}$ of blood collected was placed in the specimen bottles with Ethylene diamine tetra acetic acid (EDTA), whereas $5 \mathrm{mls}$ of the blood samples were placed in the specimen bottle without EDTA for determination of haematological and blood biochemical indices, respectively. Blood was analyzed within 3 hours of collection for red blood cell (RBC) count, haemoglobin concentration (HB), white blood cell count (WBC), packed cell volume (PCV), mean corpuscular haemoglobin $(\mathrm{MCH})$, mean corpuscular haemoglobin concentration (MCHC), mean corpuscular volume (MCV) and differential WBC counts as outlined by Ochei and Kolhatkar (2000). Blood biochemical indices analyzed included total protein, cholesterol, urea, creatinine, enzymes and the sodium, potassium, carbonate and chloride electrolytes following the procedures proposed by Ochei and Kolhatkar(2000).

\section{Statistical analysis}

Data collected were subjected to analysis of variance using the SPSS software (2012). 
Esiegwu, A.C.

Significant means were compared using Duncan's New Multiple Range Test (DNMRT) (SPSS, 2012).

\section{RESULTS AND DISCUSSION Performance of the experimental broiler finishers}

The proximate composition of garri is shown in Table 2, whereas, Table 3 shows the performance of broiler finishers fed the experimental diets. The crude protein $(1.40 \%)$ and the percent carbohydrate $(83.71 \%)$ were similar to the values $(1.27 \%)$ and $(84.55 \%)$ for proteins and carbohydrates reported by Ojo and Akande (2013). The hydrocyanic acid of garri dropped to $10.80 \mathrm{mg}$ as against the $80 \mathrm{mg} / \mathrm{kg}$ recorded for the raw cassava after fermentation and toasting. However, it was observed that 24-hours fermentation and subsequent toasting was not enough to remove all the hydrocyanic acid of the garri. As shown in Table 3 there were no significant differences $(\mathrm{P}>0.05)$ among treatments in final body weight, average daily feed intake (ADFI), and feed conversion ratio (FCR). There were however, significant $(\mathrm{P}<0.05)$ differences among treatment means in average daily weight gain (ADWG). Birds on treatment 2 (10\% garri) had the highest ADWG, and this was significantly higher $(\mathrm{P}<0.05)$ than the ADWG of birds on treatment 4 (30\% garri). Birds on treatments 1 and 3 (0 and 20\% garri) had comparable ( $\mathrm{P}>0.05)$ ADWG. However, T2 (10 \%) dietary level was significantly better than $(\mathrm{P}<0.05) \mathrm{T} 4 \quad(30 \%)$ dietary level but similar to the control and T3 (20 $\%$ ) for weight gain.

This finding is in contrast to the report of Okorie et al. (2017) whose average daily weight gain ranged from $60.42 \mathrm{~g}$ to $77.74 \mathrm{~g}$ for broiler finishers fed enzyme supplemented toasted mucuna sloanei meal and Ogbangba and George (2013) with average daily weight gain (52g to $63 \mathrm{~g}$ ) for broiler chickens fed cassava tuber meal. However, the average daily gain in this study is similar to 37.24 and $35.01 \mathrm{~g}$ for finisher broilers fed neem leaf meal at 0 and $5 \%$ dietary levels respectively (Olowu et al., 2013) The feed conversion ratio (2.85) at $10 \%$ level of inclusion was lower than 2.96 to 3.73 reported by Enyenihi et al. (2013) for broiler finishers fed gelatinized cassava tuber meal but higher than 1.76 to 2.30 for broiler chickens fed cassava tuber meal (garri) (Ogbamgba and George, 2013). The findings is in contrast with the study of Ogbamgba and George (2013) who reported better weight gain at $25 \%$ replacement level of garri for maize.

\section{Carcass characteristics}

Table 4 shows the carcass characteristics of broiler finishers fed processed cassava (garri). There were no treatment effect $(\mathrm{P}>0.05)$ on the dressing percentages and breast muscles compared to the control. The breast muscle at 20 and $30 \%$ dietary levels were comparable to the control. This implies that garri and maize are similar nutritionally and capable of tissue synthesis in finisher broilers under the same environment (Isikwenu et al., 2013). The thigh/drumstick was significantly $(\mathrm{p}<0.05)$ increased at $30 \%$ dietary level whereas the shank was significantly $(\mathrm{p}<0.05)$ decreased at $30 \%$ dietary level. The organs (gizzard, liver and heart) were not statistically affected $(\mathrm{P}>0.05)$. This implies that the anti-nutient $\mathrm{HCN}$ in the garri had no toxic or damaging effect on the carcass growth and development. This finding supports the report of Udedibie and Asoluka (2008) which stated that laying hens and older broilers have capacity to tolerate dietary $\mathrm{HCN}$ at levels up to $25 \mathrm{ppm}$.

Table 1: Ingredient and calculated nutrient composition of the experimental diet

\begin{tabular}{|c|c|c|c|c|}
\hline Ingredients & $\begin{array}{l}\mathrm{T} 1 \\
(0 \%)\end{array}$ & $\begin{array}{l}\text { T2 } \\
(10 \%)\end{array}$ & $\begin{array}{l}\text { T3 } \\
(20 \%)\end{array}$ & $\mathrm{T} 4(30) \%)$ \\
\hline Maize & 60 & 50 & 40 & 30 \\
\hline Garri & 0.0 & 10.0 & 20.0 & 30.0 \\
\hline Soybean meal & 15.0 & 15.0 & 15.0 & 15.0 \\
\hline Groundnut cake & 10.0 & 10.0 & 10.0 & 10.0 \\
\hline Fish meal & 2.0 & 2.0 & 2.0 & 2.0 \\
\hline Blood meal & 1.0 & 1.0 & 1.0 & 1.0 \\
\hline Palm kernel meal & 3.0 & 3.0 & 3.0 & 3.0 \\
\hline Wheat offal & 4.0 & 4.0 & 4.0 & 4.0 \\
\hline Bone meal & 4.0 & 4.0 & 4.0 & 4.0 \\
\hline Salt & 0.25 & 0.25 & 0.25 & 0.25 \\
\hline TM/Vit. premix & 0.25 & 0.25 & 0.25 & 0.25 \\
\hline Lysine & 0.25 & 0.25 & 0.25 & 0.25 \\
\hline Methionine & 0.25 & 0.25 & 0.25 & 0.25 \\
\hline \multicolumn{5}{|l|}{$\begin{array}{l}\text { Calculated nutrient } \\
\text { composition }\end{array}$} \\
\hline Crude protein & 20.55 & 19.55 & 18.81 & 18.08 \\
\hline $\mathrm{ME}(\mathrm{kcal} / \mathrm{kg})$ & $\begin{array}{l}2881.5 \\
3\end{array}$ & 2879.99 & $\begin{array}{l}2878.4 \\
4\end{array}$ & $\begin{array}{l}2876.9 \\
0\end{array}$ \\
\hline Ether extract & 3.85 & 33.55 & 3.26 & 2.97 \\
\hline Crude fibre & 4.02 & 4.13 & 4.25 & 4.37 \\
\hline Calcium & 1.58 & 1.58 & 1.58 & 1.558 \\
\hline Phosphorus & 1.10 & 1.08 & 1.05 & 1.02 \\
\hline Lysine & 1.27 & 1.25 & 1.22 & 1.20 \\
\hline Methionine & 0.60 & 0.58 & 0.56 & 0.54 \\
\hline \multicolumn{5}{|c|}{$\begin{array}{l}\text { *Provided the following per } \mathrm{kg} \text { of feed; vitamin A, } \\
\text { 1000iu; vitamin D3, 1500iu; vitamin E, 51mg; } \\
\text { vitamin K, 2mg; Riboflavin, 3mg; Pantothenic acid, } \\
\text { 10mg; Nicotinic acid, 25mg; Choline, 350mg; Folic } \\
\text { acid, 1mg; Mg, 56mg; Iodine, 1mg; Fe, 20mg; Zn, } \\
\text { 50mg; Co, } 1.25 \mathrm{mg} \text {. }\end{array}$} \\
\hline
\end{tabular}


Effect of Replacing Maize With Processed Cassava (Garri) on the Performance of Broiler Finisher Birds

\section{Haematological and biochemical indices}

Data on the haematological and serum biochemical indices of broiler finishers fed garri are shown in Tables 5 and 6 . The results showed that haemoglobin $(\mathrm{HB})$, packed cell volume $(\mathrm{PCV})$, red blood cell (RBC), white blood cell (WBC), mean cell volume $(\mathrm{MCV})$, and mean cell haemoglobin concenteration (MCHC), were significantly $(\mathrm{P}<$ 0.05 ) affected by treatments. The haemoglobin, packed cell volume, red blood cell and mean cell volume decreased significantly $(\mathrm{P}<0.05)$ at $30 \%$ dietary inclusion level of garri. Low values of haemoglobin and red blood cell has been implicated as signs of anaemia (Mohammed and Oloyede, 2009). The value for haemoglobin $(11.10 \mathrm{~g} / \mathrm{dl})$ at $30 \%$ dietary level was lower than the normal range $(11.60-13.68 \mathrm{~g} / \mathrm{dl})$ reported by Wikivet (2013). This was an indication that at $30 \%$ inclusion level, the feed was no longer very good for the health of the birds. The normal values of the packed cell volume and haemoglobin recorded in the present study at 10 and $20 \%$ dietary level is an indication of normal physiological functioning and effective circulatory exchange within the blood.

The values of packed cell volume from this study $(33.00 \%-39.00 \%)$ showed that $\mathrm{T} 4(30.0 \%)$ inclusion level fell below the normal range $35.9 \%-$ 41.0\% reported by Merck (1979) and Wikivet (2013). The decrease in haemoglobin, packed cell volume and red blood cell at $30.0 \%$ dietary level could be attributed to the negative effect of the anti-nutrient $\mathrm{HCN}$ that may have inhibited the absorption and utilization of nutrients resulting in the physiological upset of these cells. Haemoglobin functions to convey oxygen from the lungs through the veins to different parts of the body where it is released to burn nutrients to provide energy for body activities. A decrease in haemoglobin is a sign of reduction in nutrient metabolism and utilization hence, vital body activities such as growth, production, reproduction and other productive functions may be impeded or reduced. White blood cell decreased significantly $(\mathrm{P}<0.05)$
Table 2: Proximate composition of garri

\begin{tabular}{ll}
\hline Composition & Content $(\% \mathrm{DM})$ \\
\hline Moisture & 9.25 \\
Crude protein & 1.40 \\
Crude fibre & 3.50 \\
Ash & 1.19 \\
Ether extract & 0.95 \\
Nitrogen free extract & 83.71 \\
Metabolizable energy (Kcal/Kg) & 3.1546 \\
Hydrogen cyanide (raw cassava) & $80 \mathrm{mg} / 100 \mathrm{~g}$ \\
Hydrogen cyanide (garri) & $10.80 \mathrm{mg} / 100 \mathrm{~g}$ \\
\hline
\end{tabular}

at $20.0 \%$ and $30.0 \%$ dietary levels. This was an indication that there was no infection of the blood as a result of the anti-nutrient. White blood cell increases in the course of infection or invasion by a foreign body so as to resist them. Similarly, white blood cell differentials (neutrophils, basophils, eosinophils, monocytes and lymphocytes) showed no treatment effect $(\mathrm{P}>0.05)$. Biochemical indices affected by treatments $(\mathrm{P}<0.05)$ were urea, creatinine and serum glutamate oxaloacetate transferase (SGOT). The values showed that the diet did not affect the protein quantity and quality negatively. High level of urea is an indication of low protein quality (Nworgu et al., 2007). The urea content of the blood decreased with the inclusion of processed cassava (garri). In other words, garri consumption did not reduce the quality of the proteins at the level used. Serum enzymes are normally used to measure the toxicity of feed to the organs or damage done to the organs. An increase in serum enzymes is a sign of toxicity or damage to an organ. In this trial, alkaline phosphatase were statistically the same while serum glutamate oxaloacetate transaminase (SGOT) and serum glutamate pyruvate transferase (SGPT) decreased significantly $(\mathrm{P}<0.05)$ as the level of garri included in the diets increased. This is an indication that at these levels of inclusion, there was no deleterious effect of garri on the organs. Serum creatinine decreased significantly $(\mathrm{P}<0.05)$ with the inclusion of garri in the diet. Excess creatinine in the blood of animals is from muscle when wasting occurs and creatinine phosphate is catabolized (Yuegang et al., 2008). Significant reduction in values of creatinine was an indication of no muscle wastage.

Table 3: Performance parameters of the experimental finisher broilers fed processed cassava (garri)

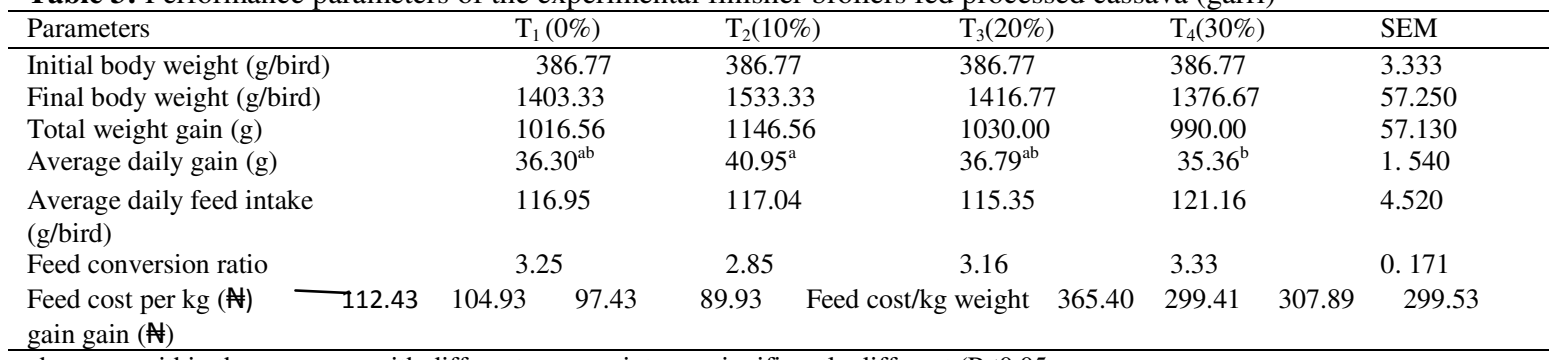

ab means within the same row with different superscripts are significantly different $(\mathrm{P}<0.05$ 
Esiegwu, A.C.

Table 4: Carcass characteristics of broiler finishers fed processed cassava (garri)

\begin{tabular}{|c|c|c|c|c|c|}
\hline Parameters & $\mathrm{T}_{1}(0 \%)$ & $\mathrm{T}_{2}(10 \%)$ & $\mathrm{T}_{3}(20 \%)$ & $\mathrm{T}_{4}(30 \%)$ & SEM \\
\hline Live weight (g/bird) & $1483.33^{\text {ab }}$ & $1566.67^{\mathrm{a}}$ & $1450.00^{\mathrm{ab}}$ & $1333.33^{b}$ & 66.144 \\
\hline Dressed weight $(\% \mathrm{LW})$ & 54.43 & 60.12 & 62.74 & 60.60 & 3. 285 \\
\hline Thigh/drum stick (\% LW) & $18.31^{\mathrm{b}}$ & $19.43^{\mathrm{ab}}$ & $16.89^{\mathrm{b}}$ & $25.58^{\mathrm{a}}$ & 2. 112 \\
\hline Breast muscles (\% LW) & $19.35^{\mathrm{a}}$ & $16.53^{\mathrm{b}}$ & $18.59^{\mathrm{ab}}$ & $18.84^{\mathrm{ab}}$ & 0.697 \\
\hline Neck (\% LW) & 1.91 & 3.21 & 2.77 & 2.93 & 0.402 \\
\hline Back (\% LW) & 5.95 & 6.78 & 7.27 & 7.69 & 0.722 \\
\hline Shank (\% LW) & $3.02^{\mathrm{b}}$ & $3.21^{\mathrm{b}}$ & $3.43^{\mathrm{b}}$ & $5.42^{\mathrm{a}}$ & 0.573 \\
\hline Wings (\% LW) & 19.10 & 16.02 & 15.38 & 18.79 & 2.28 \\
\hline Gizzard (\% LW) & 2.39 & 2.42 & 3.00 & 2.87 & 0.352 \\
\hline Liver (\% LW) & 0.57 & 2.77 & 3.22 & 3.47 & 0.607 \\
\hline Heart (\% LW) & 0.38 & 0.32 & 0.34 & 0.38 & 0.020 \\
\hline Intestinal length $(\mathrm{Cm})$ & $240.00 \quad 245.00$ & $225.00 \quad 241.67$ & 12. 2.76 & & \\
\hline
\end{tabular}

Table 5: Haematological indices of broiler finishers fed processed cassava (garri)

\begin{tabular}{|c|c|c|c|c|c|}
\hline Parameters & $\mathrm{T}_{1}(0 \%)$ & $\mathrm{T}_{2}(10 \%)$ & $\mathrm{T}_{3}(20 \%)$ & $\mathrm{T}_{4}(30 \%)$ & SEM \\
\hline $\mathrm{Hb}(\mathrm{g} / \mathrm{dl})$ & $12.00^{\mathrm{ab}}$ & $12.40^{\mathrm{a}}$ & $11.70^{\mathrm{ab}}$ & $11.10^{\mathrm{c}}$ & 0.161 \\
\hline $\operatorname{PCV}(\%)$ & $37.67^{\mathrm{a}}$ & $39.00^{\mathrm{a}}$ & $36.67^{\mathrm{a}}$ & $33.00^{\mathrm{b}}$ & 0.687 \\
\hline $\mathrm{WBC}\left(\times 10^{9} / 1\right)$ & $11.20^{\mathrm{a}}$ & $11.30^{\mathrm{a}}$ & $10.60^{\mathrm{b}}$ & $10.67^{\mathrm{b}}$ & 0.113 \\
\hline $\operatorname{RBC}\left(10^{12} / 1\right)$ & $11.97^{\mathrm{ab}}$ & $12.33^{\mathrm{a}}$ & $11.70^{\mathrm{b}}$ & $11.53^{\mathrm{b}}$ & 0.176 \\
\hline $\operatorname{ESR}\left(\mathrm{mm}^{3} / \mathrm{hr}\right)$ & $37.67^{\mathrm{ab}}$ & $33.33^{\mathrm{a}}$ & $46.67^{\mathrm{a}}$ & $46.67^{\mathrm{a}}$ & 3.333 \\
\hline MCV (fl) & $31.63^{\mathrm{a}}$ & $31.63^{\mathrm{a}}$ & $31.33^{\mathrm{a}}$ & $28.60^{\mathrm{b}}$ & 0.435 \\
\hline $\mathrm{MCH}(\mathrm{pg})$ & 10.03 & 9.93 & 10.00 & 9.63 & 0.158 \\
\hline $\operatorname{MCHC}(\mathrm{g} / \mathrm{dl})$ & $31.60^{\mathrm{b}}$ & $31.63^{\mathrm{b}}$ & $32.20^{\mathrm{b}}$ & $33.63^{\mathrm{a}}$ & 0.296 \\
\hline Neutrophils (\%) & 56.33 & 55.33 & 56.33 & 55.33 & 1.716 \\
\hline Basophiles (\%) & Nil & Nil & Nil & Nil & Nil \\
\hline Eosinophil (\%) & 01.00 & 1.67 & 1.33 & 1.33 & 0.289 \\
\hline Monocytes (\%) & 1.33 & 1.33 & 1.67 & 1.67 & 0.334 \\
\hline Lymphocytes (\%) & 41.33 & 41.67 & 40.67 & 41.67 & 1.764 \\
\hline
\end{tabular}

Table 6: Serum biochemical indices of broiler finishers fed processed cassava (garri)

\begin{tabular}{|c|c|c|c|c|c|}
\hline Parameters & $\mathrm{T}_{1}(0 \%)$ & $\mathrm{T}_{2}(10 \%)$ & $\mathrm{T}_{3}(20 \%)$ & $\mathrm{T}_{4}(30 \%)$ & SEM \\
\hline Urea (mmol/L) & $6.60^{\mathrm{a}}$ & $5.63^{c}$ & $6.03^{\mathrm{c}}$ & $5.63^{c}$ & 0.09 \\
\hline Creatinine $(\mathrm{mmol} / \mathrm{L})$ & $62.27^{\mathrm{a}}$ & $53.00^{\mathrm{c}}$ & $55.33^{\mathrm{c}}$ & $56.67^{\mathrm{c}}$ & 1.47 \\
\hline Cholesterol (mmol/L) & 7.27 & 7.40 & 7.30 & 7.53 & 0.219 \\
\hline Total protein $(\mathrm{g} / \mathrm{d})$ & 57.00 & 53.67 & 57.00 & 55.67 & 2. 461 \\
\hline Globulin $(\mathrm{g} / \mathrm{d})$ & 34.00 & 32.00 & 33.33 & 34.00 & 4.121 \\
\hline $\operatorname{Albumin}(\mathrm{g} / \mathrm{d})$ & 23.00 & 21.67 & 22.67 & 21.67 & 1.447 \\
\hline Sodium (mmol/L) & $41.67^{\mathrm{ab}}$ & $39.00^{\mathrm{c}}$ & $40.00^{\mathrm{bc}}$ & $42.67^{\mathrm{a}}$ & 0.687 \\
\hline Potassium (mmol/L) & 1.17 & 1.1 & 1.13 & 1.27 & 0.071 \\
\hline Bicarbonate $(\mathrm{mmol} / \mathrm{L})$ & $10.93^{\mathrm{ab}}$ & $10.42^{\mathrm{b}}$ & $10.87^{\mathrm{b}}$ & $11.47^{\mathrm{a}}$ & 0.195 \\
\hline Chlorine (mmol/L) & 22.67 & 23.00 & 23.00 & 25.00 & 1.098 \\
\hline Alk. phosphate & 1.17 & 1.10 & 1.13 & 1.13 & 0.071 \\
\hline SGOT & $11.80^{\mathrm{a}}$ & $11.50^{\mathrm{ab}}$ & $11.57^{\mathrm{ab}}$ & $11.40^{\mathrm{b}}$ & 0.105 \\
\hline SGPT & $7.33^{\mathrm{a}}$ & $16.97^{\mathrm{b}}$ & $6.93^{\mathrm{b}}$ & $6.93^{\mathrm{b}}$ & 0.105 \\
\hline
\end{tabular}

\section{CONCLUSION}

From the result of the present study, it was observed that broilers on $10 \%$ dietary inclusion level of garri had improved weight gain. Dietary inclusion of cassava processed meal based diet (garri) did not exert any deleterious effect on carcass, organ weights and blood indices of broilers. Therefore, it is recommended that the use of garri as an alternative energy source in the diet of broilers should not exceed 10\% inclusion level, due to its cost effectiveness at this level.

\section{REFERENCES}

Accuweather(2015). Weather for Owerri, Nigeria. http://www.accuweather.com/en/ng/owerri/253317/ weather-forecast/253317.Retrieved on November 15 2015.

AOAC (2010). Official methods of analysis. $19^{\text {th }}$ edition. Association of official Analytical chemists. Washington D. C. USA.

Chauynarong, N., Elangovan, A. V. and Iji, P. A. (2009). The potential of cassava products in diets for poultry. Worlds Poultry Sci. J., 65: 23 - 35.

Demoranville, V. E. and Best, M. A. (2013). Haematocrit. Encyclopedia of surgery. A guide for patients and caregivers. Available at: enwikipedia.org/wiki/haematology. 
Effect of Replacing Maize With Processed Cassava (Garri) on the Performance of Broiler Finisher Birds

.Enidiok, S. E., Attah, L. E. and Otuechere, C. A. (2008). Evaluation of moisture, Total cyanide and Fiber contents garri produced from Cassava (Manihot utilissima) varieties obtained from Awassa in Southern Ethiopia. Pakistan Journal of Nutrition 7 (5): $625-629$.

Enyenihi, G. E., Esiegwu, A. C., Esonu, B. O., Uchegbu, M. C. and Udedibie, A. B. I. (2013). Gelatinization of fermented cassava tuber meal and its nutritive value for broilers. Nigerian Journal of Animal Production. Volume 40 (2): 71 - 79.

Ernesto, M. Cardoso, A. P., Cliff, J. and Bradbury, J. H. (2000). Cyanogens in cassava flour and roots and urinary thiocyanate concenteration in Mozambique. Journal of Food Composition and Analysis, 13: 1 - 12 .

Esiegwu, A. C. (2017). Effect of fermented sorghum seed meal on the performance, carcass characteristics and blood profile of broiler finisher chicken. Nig. J. Anim. Prod. 44(3): 300 - 308.

Isikwenu, J. O., Akpodiete, O. J., Omeje, S. I. and Okagbare, G. O. (2010). The effects of replacing groundnut with urea-treated and fermented brewer's dried grains on nutrient digestibility, retention and carcass characteristics of broiler finishers. Nig. J. Anim. Prod. 37(1): $1-12$.

IITA (International Institute of Tropical Agriculture) (2002). Competitiveness workshop in opportunities for cassava in Nigeria. Book anga, IITA. Ibadan.

Merck Veterinary Manual (1979). A handbook of diagnosis and therapy for veterinarians. $5^{\text {th }}$ edition. Merck and Co. Inc. Rahway. N. J. USA p.21, 1613.

Mohammed, N. O. and Oloyede, O. B. (2009). Growth performance of broiler chicks fed Aspergillus niger-fermented Terminalia catappa seed meal based diet. Global Journal of Biotechnology and Biochemistry. 4(2): $179-183$.

Nworgu, F.C.,Ogungbenro, S.A. and Solesi, K.S. (2007). Performance and some blood chemistry indices of broiler chickens served fluted pumpkin (Telfariaoccidentalis) leaves extract supplement. American Euraisan Journal of Agric. and Environ.Science. 2(1): 90 - 98.

Ochie, J. and Kolhatkar, A. (2000). Medical laboratory science. Theory and practice. Tata McGraw-Hill company limited New Delhi.

Ogbamgba, K. O. and George, S. O. (2013). Effect of processed cassava tuber meal (garri) on the performance and serum metabolites of broilers. International Journal of Science and Research. Volume 4 Issue 32319 - 7064.
Ojo, A. and Akande, E. A. (2013). Quality evaluation of garri produced from cassava and sweet potato tuber mixes. Afr. J. Biotechnol. Vol. 12 (31): 4920 4924.

Okorie, K. C., Esiegwu, A. C. and Okonkwo, V. N. (2017). Effect of enzyme (Zympex 0.8) supplementation on performance and blood indices of finisher broilers fed diets containing toasted Mucuna sloanei meal. Int'l Journal of Agric. And Rural Dev. Vol. 20(1): 2986 - 2992.

Olowu, O. P. A., Asaniyan, E. K. and Agbede, J. O. (2013). Performance, organ characteristics and economics of finisher broiler fed neem (Azadirachta indica) leaf meal as a replacement for maize. Nigerian Journal of Animal Production, Vol.40(2): $45-51$.

Purves, W. K., Sadava D., Onans, G. H. and Heller, H. C. (2003). Life: the science of biology $\left(7^{\text {th }}\right.$ ed.) Sunderland, mass associates 954.

SPSS (2012). Statistical package for social sciences, version 21. USA IBM Corporation.

Tsegai, d. and Kormawa, P. C. (2002). Determinant of urban household demand for cassava products in Kaduna, Northern Nigeria. In: Conference of international research for development, Witzenhause, 9-10 October.

Udedibie, A. B. I. (2007). Wetting method improves nutritive value of cassava for broilers in Nigeria. Cassava Cyanide Diseases Network News, 9: 1- 2.

Udedibie, A. B. I., Alozie, I. L. and Duru, H. I. (2007). Effects of 12-hour wetting of sun-dried cassava tuber meal on its $\mathrm{HCN}$ content, performance and haematological indices of broiler chicks. Anim. Prod. Res. Adv., 3: 1-5.

Udedibie, A. B. I., Anyaegbu, B. C., Onyechekwe, G. C. and Ogbukporo, O. C. (2004). Effects of feeding different levels of fermented and unfermented cassava tuber meals on performance of broilers. Nig. J. Anim. Prod., 31: $211-219$.

Udedibie, A. B. I. and Asoluka, C. O. (2008). Effects of 5-hour wetting of sun-dried cassava tuber meal on the $\mathrm{HCN}$ content and dietary value of the meal for young chicks. Nig. J. Anim. Prod., 35: 25 - 31.

Wikivet. Haematology (2013) available at en.wikipedia/wiki/haematology.

Yuegang, Z., Chengjum, W. and Chengjum, T. (2008). Simultaneous determination of creatinine and uric acid in human urine by high performance liquid chromatography. Analytic science. 24: 1589 - 1592. 